\title{
Ioan Milică, Lumi discursive. Studii de lingvistică aplicată, Editura Junimea, Iași, 2013, 294 p.
}

\author{
Enikő Pál* \\ Facultatea de Științe Economice și Umaniste, Universitatea Sapientia, Piața Libertății 1, 530104 Miercurea Ciuc, România
}

În epoca noastră, în care științele limbajului cunosc o extraordinară diversificare a preocupărilor științifice, în rîndul cărora cercetările de lingvistică aplicată ocupă un loc privilegiat, o carte care vorbește despre ipostazele comunicării verbale își găsește o rațiune bine justificată, printre altele, prin actualitatea ei. $\mathrm{Ne}$ referim la volumul de studii reunite sub titlul, extrem de frapant și de expresiv, Lumi discursive..., semnat de Ioan Milică și apărut la Editura Junimea din Iași în 2013. De altminteri, titlul are menirea de „a atrage atenția asupra faptului că firele de legătură a studiilor cuprinse în volum se reunesc în interpretarea actului lingvistic drept o lume dinamică, adaptativă”, aşa cum mărturisește autorul (p. 13). În esență, volumul reflectă interese de cercetare de durată, unele dintre problemele discutate constituind preocupări constante ale autorului. Astfel, revizuind și îmbogățind cercetarea, cartea de faţă întrunește rezultatele obținute anterior de către autor, dar care se găseau diseminate în diverse publicații și volume științifice.

Problematica fundamentală care este tratată de-a lungul a aproape trei sute de pagini nu este cu totul inedită. Prin extindere, volumul se alătură lucrărilor de specialitate care vizează analiza textului și a discursului, tematică care a trezit, de mai multă vreme, interesul specialiștilor, ea fiind revendicată de mai multe științe ale limbajului. În plan mai restrîns, volumul se încadrează în seria lucrărilor de lingvistică aplicată în care se valorifică latura semiotică a concretului comunicării verbale. Se remarcă însă noutatea notabilă pe care volumul de faţă o aduce în aceste domenii de cercetare. Astfel, cu diverse ocazii, autorul pune într-o lumină nouă vechile abordări și/sau propune el însuși abordări noi și, în același timp, oferă un material lingvistic nou. Recunoscînd faptul că orice teorie lingvistică trebuie sprijinită de evidențe din realitatea vorbirii, la fel cum orice cercetare aplicată trebuie bazată pe un suport teoretic solid, autorul găsește acea cale de mijloc care împacă și pe una și pe cealaltă. În acest fel, asistăm la o reconfigurare originală a felului cum se pot interpreta unele acte de vorbire din spațiul public și/sau din cel privat.

Dezbaterea propriu-zisă a "lumilor discursive” propuse spre analiză în această carte este precedată de o Introducere în care autorul face unele considerații cu privire la fundamentul teoretic al studiilor incluse în volum, trecîndu-se în revistă şi principalele coordonate ale lingvisticii aplicate căreia îi este rezervat rolul de a cuprinde eterogenitatea faptelor de comunicare verbală. Dincolo de delimitarea ei teoretică față de alte preocupări ale științei limbii ${ }^{1}$, autorul arată şi unele consecințe benefice pe care lingvistica aplicată le-a avut pentru cercetările lingvistice.

După această parte introductivă, autorul ne călăuzește prin trei „lumi discursive”: lumea discursului public, universul proverbelor și sferele terminologiilor populare şi culte întrebuinţate pentru a exprima cunoștințe, noțiuni și idei, acestea constituind și secțiunile volumului. Expunerea este concepută sub forma unor studii de caz (în fiecare secțiune, cîte trei) dezvoltate în jurul unor realităţi comunicative extrem de complexe. Studiile de caz cuprinse în volum se caracterizează printr-o unitate de viziune, fenomenele lingvistice fiind analizate prin raportare la articularea lor semiotică. În același timp, autorul studiază fiecare fenomen analizat în acord cu natura sa, reuşind să reliefeze aspectele sale distinctive.

Prima secțiune, Discursul public, reunește studii de caz care pun în evidență fenomene prezente în comunicarea politică și mediatică. În primul studiu, Ideologie și limbaj, autorul configurează discursul totalitar prin raportare la texte publicistice și juridice

*Adresă de corespondență: enikopaldr@gmail.com.

${ }^{1}$ De altminteri, autorul arată, în mod just, relativitatea distincției saussuriene. Astfel, potrivit autorului, în realitatea cercetării, nu există o „lingvistică a limbii” (lingvistică teoretică), ci teorii lingvistice concurente, după cum nu există o „lingvistică a vorbirii” (lingvistică aplicată), ci practici de analiză și descriere lingvistică (p. 8). 
şi la realităţi lingvistice precum onomastica şi toponimia urbană cu motivare ideologică. Acesta este urmat de studiul Cuvintele discordiei, în care autorul stabilește, pe drept, violența de limbaj ca prezență în discursul politic românesc actual. Aici se valorifică aspecte precum prezența argoului în declarațiile politice ale parlamentarilor români, inventariind și alte „anomalii” sau fenomene lingvistice incompatibile cu specificul structural și funcțional al discursului politic. Exemplele oferite de autor în acest sens sînt extrem de instructive. Ultimul studiu din această sferă de interes, Embleme onomastice, se remarcă prin observațiile pertinente ale autorului în legătură cu agresarea numelor de persoană în sfera publică.

În cea de-a doua secțiune, Universul proverbelor, sînt discutate cîteva fenomene discursive fundamentale pentru interpretarea adecvată a folosirii proverbelor în comunicarea verbală. Astfel, în primul studiu, Gramaticalizare și stilizare paremiologică, se prezintă unele tipare structurale și ornamentale ale paremiilor, țelul autorului fiind acela de a propune o tipologie a actualizărilor contextuale ale formulelor paremiologice. Următorul studiu, „Vorba ceea”, exploatează unele modalități de ancorare a acestor enunțuri sapiențiale în discurs. Extrem de interesant ni se pare ultimul studiu al acestei secțiuni, Stigmate proverbiale, în care proverbele sînt prezentate în calitatea lor de embleme imagologice, autorul propunînd discutarea problemei stereotipurilor reflectate în aceste vorbe de înțelepciune. Considerăm că universul parimiilor, extrem de fascinant și în sine, devine și mai interesant atunci cînd aceste cugetări populare dobîndesc calitatea de elemente ale unui „discurs repetat" ${ }^{2}$. În acest sens, studiile acestei secțiuni arată cu desăvîrșire vitalitatea extraordinară a proverbelor și calitatea lor de izvor neîncetat de inspirație, inclusiv pentru actele lingvistice cotidiene.

Ultima secțiune, Modele naive, modele savante, include studii în care se valorifică materialul oferit de terminologia populară și științifică. Deși aparent plasat în afara „lumilor discursive” discutate anterior, cuprinderea în volum a acestei arii de cercetare este motivată prin faptul că terminologiile, la rîndul lor, reflectă viziuni asupra lumii. Pe de altă parte, studiul terminologiilor este util în a arăta că unele din lumile discursive au caracter, prin excelență, metaforic. Astfel, în primul studiu, Modele cognitive și oglindirifigurative, autorul trece în revistă terminologia botanică, insistînd asupra proprietăților modelului popular și savant de numire a plantelor și asupra domeniilor onomasiologice reflectate în planul semantic al denumirilor etnobotanice și științifice. Un alt studiu, Imaginarul animalier în presa sportivă contemporană, îi este dedicat poreclelor și supranumelor de sorginte animalieră care sînt de uz curent în presa sportivă românească și internaţională. Seria studiilor de lingvistică aplicată se încheie cu unele considerații asupra trăsăturilor și funcțiilor metaforei în discursul științific care constituie obiectul studiului de caz intitulat Metafora științifică.

Unul dintre punctele forte ale prezentului volum îl constituie caracterul interdisciplinar al analizelor operate de autor. Astfel, faptele de limbă nu sînt studiate unilateral, adică exclusiv din unghiul unui singur suport metodologic, ci ele sînt privite prin prisma a diverse aspecte, autorul recurgînd la o suită de metode și instrumente de analiză aparținînd mai multor domenii științifice, lucru, de altfel, cerut și de natura și complexitatea materialului lingvistic interpretat. În acest fel, autorul reușește să pună în evidență solidaritatea dintre faptele de limbă și situațiile de comunicare în care acestea sînt întrebuințate.

Rezultatele cercetărilor întreprinse de autor sînt raportate cu deosebită competență la cercetările anterioare de lingvistică teoretică şi aplicată. Mai mult decît atît, cartea invită și cititorul la reflecție, pe măsură ce analiza interoghează ipoteze și oferă explicații formulate de alți specialiști sau de însuşi autorul lucrării de față. În acest sens, trebuie remarcată și atenţia cu care autorul îşi sprijină afirmaţiile și modul corect, ştiințific în care prezintă și explică faptele de limbă extrase. Perspectiva funcțională, centrală în investigația întreprinsă de autor antrenează în mod firesc evaluări şi reevaluări ale faptelor de limbă discutate. Chiar şi cînd vine vorba despre unele aspecte mai delicate, cum este discursul politic totalitar sau actual, autorul

\footnotetext{
${ }^{2}$ Avem în vedere aici accepția pe care o dă E. Coșeriu acestui concept: „tot ceea ce în vorbirea unei comunități se repetă într-o formă mai mult sau mai puțin identică sub formă de discurs deja făcut sau combinare mai mult sau mai puțin fixă, ca fragment lung sau scurt, a «ceea ce s-a spus deja»” (în Lecții de lingvistică generală, Chișinău, Editura Arc, p. 258) și, pe urmele acestuia, Stelian Dumistrăcel: „«prefabricate de vorbire» cum sunt proverbele, locuțiunile fixe expresive, formulele de comparație, citatele de autor etc., inserate, prin «colaj», în enunțul ce constituie produsul «tehnicii libere a vorbirii»” (în Discursul repetat în textul jurnalistic. Tentația instituirii comuniunii fatice prin mass-media, Editura Universității „Alexandru Ioan Cuza”, Iași, 2006, p. 7).
} 
păstrează tonalitatea neutră, dînd dovadă și de discernămîntul cu care se îmbină prudența și curajul în dezvoltarea demersului său interpretativ.

Selecția problemelor aprofundate în acest volum a necesitat parcurgerea unei vaste bibliografii pe care autorul a valorificat-o critic, reușind să articuleze o viziune coerentă asupra lumilor discursive a spațiului public, a universului proverbelor și a sferei terminologiilor. Cercetarea întreprinsă în volumul de față este una destul de amplă, bine organizată, avînd o structură echilibrată, și extrem de eficientă. Autorul dă dovadă nu numai de spirit științific, ci și de o creativitate și originalitate. Demonstrațiile sînt expuse urmînd o logică desăvîrșită, iar stilul autorului se caracterizează prin claritate, precizie și, lucru remarcabil, printr-o vitalitate care, de altminteri, este caracteristică și celorlalte scrieri ale sale. În acest sens, trebuie să evidențiem faptul că exemplele excerptate de autor din diverse texte politice, juridice etc. sînt nu numai pertinente și foarte instructive, ele prezentînd numeroase oportunități pentru cercetări ulterioare, ci, în acelaşi timp, oferă și o adevărată plăcere a lecturii.

În ansamblu, studiile de lingvistică aplicată cuprinse în acest volum prospectează teritorii de limbaj mai puțin valorificate, iar, prin punerea în practică a unor metode adecvate de lucru, ele permit unele generalizări care contribuie la completarea modelelor și abstractizărilor teoretice curente. Neepuizînd toate valenţele și bogăţia de aspecte cuprinse în secțiunile lucrării Lumi discursive..., recomandăm cartea semnată de Ioan Milică drept o contribuție valoroasă la cercetările de lingvistică aplicată care merită atenția nu numai a unui cerc mai restrîns de specialiști în domeniu, ci și cea a unui public mai larg. 